\title{
THE EUROPEAN JOURNAL OF LIFE WRITING
}

VoLUMe X (2021) BB135-BB154

\section{New Female Role Models from Around the World: Goodnight Stories for Rebel Girls}

\author{
Marleen Rensen \\ University of Amsterdam
}

\section{Abstract}

Biographies for children have always been popular among young readers, but they are becoming an increasingly important part of children's literature in the twenty-first century. Most prominent are the collections offering short life-sketches of historical and contemporary figures who can serve as positive role models for young readers from diverse backgrounds. This article discusses the international bestseller Goodnight Stories for Rebel Girls: 100 Tales of Extraordinary Women (2016) from a feminist, transnational perspective. Focusing on the authors' narrative strategies, it investigates how tropes of agency are used to make aware of women's struggles and successes across time and space. Further, it examines how girls are actively encouraged to continue these legacies. Ultimately, the analysis shows that Goodnight Stories establishes connections between women from diverse countries and continents, and at the same time reveals cross-cultural differences in how the book has been received in different corners of the world.

Keywords: biographies for children, female role models, diversity, transnationalism

\section{Samenvatting}

Biografieën voor kinderen zijn altijd populair geweest, maar ze eisen een steeds belangrijker aandeel op in de jeugdliteratuur van de eenentwintigste eeuw. Het meest prominent zijn de geïllustreerde boeken met korte biografische schetsen van mensen uit heden en verleden die positieve rolmodellen kunnen zijn voor jonge lezers met diverse achtergronden. Dit artikel bespreekt de internationale bestseller Bedtijdverhalen 
voor rebelse meisjes. 100 Verhalen over bijzondere vrouwen (2016) vanuit een feministisch, transnationaal perspectief. Kijkend naar de vertelstrategieën van de auteurs, analyseert dit artikel hoe tropen van agency gebruikt worden om kinderen bewust te maken van de strijd en het succes van vrouwen overal ter wereld, door de eeuwen heen. Ook onderzoekt het op welke wijze meisjes er actief toe worden aangezet om die erfenissen voort te zetten. De analyse laat, tot slot, zien dat Bedtijdverhalen relaties legt tussen vrouwen uit diverse culturen en continenten, maar toont ook dat er cultuurverschillen zijn in de manier waarop het boek in verschillende delen van de wereld ontvangen is.

Trefwoorden: biografieën voor kinderen, vrouwelijke rolmodellen, diversiteit, transnationalisme

\section{Introduction}

If children's books appear in the news today, it is often because they generate debate about the appropriateness of gendered and racial/ethnic representations. An exemplary case in point is Elena Favilli and Francesca Cavallo's book Goodnight Stories for Rebel Girls (2016), which recently became the subject of controversy in Turkey. This international bestseller presents an illustrated collection of 100 short biographies of women from both the past and present, with the aim of providing young readers with powerful female role models. The featured women include, among others, Catherine the Great, Marie Curie, Frida Kahlo, Rosa Parks, Michelle Obama, and Malala Yousafzai. In October 2019, Turkey's government decided to partially ban the Turkish edition of the book. According to the official statement, some sections were judged to have a 'detrimental influence' on young people under the age of eighteen. ${ }^{1}$

Most probably, this decision can be explained by the fact that the book overtly promotes gender equality and includes entries on lesbian and transgender subjects. The Turkish government followed the advice of their Board for the Protection of Minors, who deemed Goodnight Stories an 'obscene publication', which should be treated as if it were 'pornography'. The implications of this judgement are that the book can only be sold to adults and must be 'concealed from view' in shops. Interestingly, it would seem that the Turkish government takes stories of women's lives very seriously and assumes that 'children's literature can have and is having a real impact'. ${ }^{2}$

The ban in Turkey encapsulates the two main themes of this article's discussion of Goodnight Stories: its impact on young readers; and its transnational circulation and 
reception. In studying the book, it is important to attend to its impact because the authors obviously want to inspire young girls and teach them to 'rebel', thus creating a 'revolution at bedtime'. Indeed, sales figures indicate that their book has a powerful appeal. This is widely seen as typical of children's biography as such. As critics of the genre have observed, the life stories of prominent individuals have long made up a significant portion of Western educational culture. They have been used to bring the past alive in history lessons and provide moral examples in religious education. ${ }^{3}$

Partly because biographies for children have often been so moralistic and openly didactic in purpose, the genre has never received much scholarly interest. Even within the field of children's literature, of which biography is an important category, it is often considered mediocre in comparison to fictional stories when it comes to style and aesthetics. That being said, a few critics (such as Sarah VanderHaagen, Ivy Linton Stabell, and Clementine Beauvais) have shown that biographies intended for children deserve more attention. In particular, they have highlighted its distinct capacity to engage readers and help rethink issues of genre and society. As Stabell has argued: these texts 'are inhabited by adult concerns about the fate of the children reading the text, and by the symbolic weight of the child as representative of the community's future [...] they offer a vital genre for exploring a community's ambitions and fears' ${ }^{4}$ A critical reading of biographies for children can, for example, illuminate which views on agency and gender figure in the public imagination. Building on the work of these and other critics, this article will analyse the narrative strategies and forms through which Goodnight Stories presents lives of adult women (and a few adolescents) as role models for children. Which strategies do they use to engage and empower young readers and how does this relate to other uses of the genre in progressive activism, such as the human rights and black feminist movements?

The second theme-Goodnight Stories' cross-border readership-is equally interesting. This is because the book includes women from every corner of the world and has been circulated across countries and continents. Soon after it first appeared, the book was widely translated and is currently available in 47 languages, ranging from English, French, German, Croatian, Czech, Danish, Dutch, Estonian, Hungarian, Spanish, and Russian to Japanese and Korean. How does this children's book, having been written by two Italian-born authors, reach across national boundaries and cater to a global audience? And how is it received and translated in different countries? Looking at the selection of women and the ways in which they are presented in different language editions, this article explores these questions in the light of transnationalism, life writing, and feminist studies. 


\section{Empowering young girls}

Although biographies for children have always been popular among young readers, they are becoming an increasingly important part of children's literature in the twentyfirst century. There has been a steady rise in the number of such publications since the 1980s, which seems to have reached a peak between 2010 and 2020. As Beauvais puts it: 'Inspirational biographies for children are not just surviving, they are thriving'. ${ }^{5}$ The corpus is diverse: biographies are published in the form of series and single stories; full-fledged and partial life-sketches; fictional and non-fictional books. In addition to the high sales figures, the genre seems more appreciated than ever before in terms of literary awards and prizes. ${ }^{6}$

Goodnight Stories is definitively part of this wider development in the field of children's literature. The book not only received multiple awards ${ }^{7}$, but could have been considered a success even before its publication. As the authors Elena Favilli and Francesca Cavallo write in their preface, while writing the book they managed to bring in a 'record breaking amount of money' through crowdfunding. ${ }^{8}$ Goodnight Stories became one of the most successful projects and 'the quickest and most funded children's book in the history of crowdfunding' ${ }^{9}$ Two sequels ${ }^{10}$ have appeared since the first publication: one collects the tales of another 100 extraordinary women; the other is devoted to 100 'immigrant women who changed the world'. Besides the books, a podcast series has been launched, along with an extensive collection of gift sets, including a diary, postcards, calendars, colouring books, et cetera. According to the authors, the intended readership is eight to ten years of age if the children are to read the stories themselves, although the stories can also be read to children 'as young as four years old'. ${ }^{11}$

The success of Goodnight Stories is all the more remarkable given that the idea of using life stories to teach children is in itself neither new nor exceptional. The educational culture mentioned above, in which biographies figure prominently, has its roots in the old tradition of 'exemplary lives'. This primal form of biography, or 'ur-biography' as Hermione Lee calls it, has two major strands: the classical lives written by Plutarch, Suetonius, and others; and the saints' lives (or hagiographies) that became dominant in the medieval period. Regardless of the differences between these strands, they share a didactic purpose. In exploring outstanding people's lives, they hold up moral examples. Whether they are positive or negative, these exemplars serve to teach readers a lesson. By way of relatively short, anecdotal sketches, they aim to impress the reader with amazing facts about someone's biography or personality. Therefore, 
exemplary lives reveal only certain facts of a life, events, or character traits, and completely ignore others. This tradition of life writing has had a longstanding influence. Despite being criticised in the modern period on account of its idealising tendency and lack of attention to the 'full' lives of its subjects, it has never ceased to exist. ${ }^{12}$ Today, the success of biographical books for children, such as Goodnight Stories, suggests that it is enjoying a rather spectacularly resurgence.

Nevertheless, in line with feminist and postcolonial criticism in both the practice and study of life writing, Goodnight Stories counters the biographical tradition of 'great men' by drawing attention to the lives of female, black, and queer subjects, which have been overlooked or belittled over history. In the last decade, a number of similar books have appeared on the children's book market that also celebrate 'diversity'. Worth mentioning in this regard are the series Little People, Big Dreams (2015); Ben Brooks' Stories for Boys Who Dare to be Different (2017); Stories for Kids Who Dare to be Different (2018); and Janny van der Molen's Heroines (Heldinnen, 2018). The frames and forms of the latter two books resemble those of Goodnight Stories both books aim to inspire children by compiling short, one-page biographies of both historical and contemporary men and women. Each story is accompanied by a graphic portrait of the featured person, which helps bring the subject to life. Of all these series, Goodnight Stories seems to be the most successful when it comes to sales figures and the number of translations.

Goodnight stories also stands out for being all-female: the book is about women, for (young) women, and made by women. Favilli and Cavallo wrote the stories and asked over sixty female artists to illustrate the biographical sketches with eye-catching, fullcolour portraits. In their preface to the book, the authors explicitly state that they want to empower girls by making them aware of women's role in history and showing what women are capable of:

No matter the importance of their discoveries, the audacity of their adventures, the width of their genius - they [women] were constantly belittled, forgotten, in some cases almost erased from history [...].

It is important that girls understand the obstacles that lie in front of them. It is just as important that they know these obstacles are not insurmountable. That not only can they find a way to overcome them, but that they can remove those obstacles for those who will come after them (xi-xii). 
Hence, the feminist educational purpose of the book is crystal clear. Investigating the first volume of Favilli and Cavallo's series, this article will examine how does this purpose play out at the level of the story. Through which narrative frames and forms does the book tell the stories of the selected women's lives? And how does it address young readers?

\section{New princesses: The frame and form of narration}

Each of the 100 women portrayed in Goodnight Stories are special in their own way. Although some are famous figures, such as Astrid Lindgren, Evita Péron, and Malala, many others are lesser-known. As the authors relate in an interview, diversity was one of their key criteria when it came to selecting their subjects: they wanted to include women from across the globe so as to be as diverse and inclusive as possible in terms of geography and cultural background..$^{13}$ Ideally, every young girl will be able to find at least one woman to identify with. Accordingly, the presented subjects come from different countries and continents. Some are black, others are white; some wear a veil, others do not; some are straight, others are gay, and still others are transgender; and some have a disability while others do not. They earned their distinction in diverse areas: arts, sciences, politics, sports, entertainment, or other fields. The table of contents lists the names of the women and mentions their profession or occupation, which immediately emphasizes the women's merits and achievements. It includes queens, presidents, prime ministers, and those in prestigious intellectual professions, such as writers, doctors, and computer scientists. What is more, it features women with exciting or 'cool' occupations, such as sailors, pirates, spies, explorers, mountaineers, drummers, boxers, and weightlifters.

The authors have carefully crafted the stories with children in mind: they present the lives of the 100 selected women in short, one-page stories, which are comprehensive and easy to read. Clearly, their lives are not treated comprehensively. Put differently, the biographical sketches in the book are limited in coverage. In the same vein as exemplary lives in the Plutarchian tradition, they only present a few remarkable anecdotes, facts, and quotations, which bring out the women's exceptional character. Indeed, Goodnight Stories seems to follow the dictum that 'Biographies for children and young people are meant to be memorable', ${ }^{14}$ as VanderHaagen puts it. They should make an impression on the reader.

Interestingly, Favilli and Cavallo use the narrative form of the fairy tale-a typical children's story - in rewriting the genre of biography. All stories begin with a variation 
on a sentence that children are familiar with. Accordingly, the famous female aviator Amelia Earhart is introduced thus: 'Once upon a time, a girl called Amelia saved enough money to buy a yellow airplane'. ${ }^{15}$ This opening sentence draws young readers into the story and appeals to their imagination. In telling vivid and witty modern fairy tales, the authors present the biographical material in a creative way. The biography of the astronomer Jill Tarter, for example, opens with the lines: 'Once there was a girl who wanted to become friends with the stars. Her name was Jill'. The dates of birth and death of the woman portrayed are mentioned at the bottom of the page at the end of each story, subtly reminding the reader that these stories are real. It is likely that children are even more impressed by a given tale when they know that it tells the true story of a heroine who actually lived or is even alive today.

Even though there are neither dragons, elves, nor witches, another element of the stories - besides the opening phrase-signals that they are fairy tales: there is usually a happy ending, which looks towards a bright future. The biography of Miriam Makeba, the South-African activist and singer who was long imprisoned for her antiapartheid songs, is typical in this regard. It ends with the following lines: 'After thirtyone years she was allowed back home. Shortly afterward, apartheid was finally crushed'. As so often in biographies for children, certain painful facts are glossed over, most likely 'to shield children of life's harshness' ${ }^{16}$ Virginia Woolf's suicide, for example, goes unmentioned. ${ }^{17}$ The story of her life does note, though, that she suffered from mental depression. In spite of this, her biography ends on a hopeful note: 'Today, depression can be treated. But whether you are happy or sad or something in between, it is always a great idea to record your moods in a diary. You may become a writing genius like Virginia, and help other people understand their feelings and live lives full of dreams' (184).

The authors borrow the narrative form of the fairy tale only to 'reinvent' the pink princesses' genre. ${ }^{18}$ Since the 1970 s feminist scholars of fairy tales have debated the representation of female characters in the genre and its effects on children's view of gender roles. Whereas certain critics have emphasised that some fairy tales can have positive, liberating effects on female readers, others have argued in response that many well-known tales perpetuate traditional gender roles. ${ }^{19}$ Snow White, Sleeping Beauty, and Rapunzel are helpless heroines, who must wait for their princes to rescue them and make them happy. They have no agency. Although other female characters-such as witches, evil stepmothers, and jealous stepsisters-may have some capacity to act, for the most part, they are motivated by negative emotions. What is more, in the end, they are usually defeated by male warriors. In an interview, Favilli and 
Cavallo state that they wanted to fight such gender stereotypes, which still predominate in popular children's stories in fiction, film, and television. Given that it portrays powerful female characters, who have strong wills and act autonomously, their book is sometimes referred to as the 'anti-princess story book' ${ }^{20}$ It is more accurate, perhaps, to say that the authors aim to present a new type of princess. This is best exemplified in their sketch of the life of Brenda Chapman (born 1962), an animation director working for Disney, who created strong and independent female characters for popular films, such as Princess Merida in Brave.

Favilli and Cavallo clearly want to break down gender stereotypes and challenge prevailing ideas about what it means to be a girl. However, the extent to which their book can be considered truly progressive, or progressive enough, has been called into question. Critics have argued that Goodnight Stories might actually even reinforce prevailing conceptions of gender by only targeting girls in its title and foreword. This serves to divide readers by gender, suggesting there are boy-books and girl-books and assuming that only girls will be interested in the lives of women. ${ }^{21}$ On social media, some parents wrote that their son loved the book but 'was embarrassed to admit he liked a book for girls'. ${ }^{22}$ Children who are neither boyish nor girlish may also feel excluded by the way in which the book exclusively addresses girls. In addition to drawing attention to how the book segregates its readership, critics have argued that its message should be disseminated among all readers. Boys also need to become aware that women are as capable and active as men and that women are behind some of the greatest achievements in history. The authors of Goodnight Stories, though, choose to focus first and foremost on girls, although they are clearly aware of the need to educate boys as well. As they write on the website of their Kickstarter campaign: 'by any means, read these stories to your sons! It is crucial that they learn to identify and empathize also with female heroes! The stories in the book are a great source of inspiration for anyone, male or female, child or adult' ${ }^{23}$

\section{Tropes of female agency}

The majority of Favilli and Cavallo's biographical sketches are structured around tropes of female agency, much like biographies for children in the black feminist tradition. ${ }^{24}$ Given their book's title, it comes as no surprise that rebellion is the first central trope in the presented women's lives. Many of the subjects portrayed rebel against parents, political regimes, and societies to achieve what they want. Almost all of the 
stories highlight that although the young heroines have dreams, fantasies, and passions, opportunities are limited. Prevailing circumstances of the age or place in which they grow up make it difficult to realise their ambitions, whether they be dictatorship, illness, poverty, racism, or the pressure of parental and societal expectations.

Many of the stories stress that the women were or are confronted with gender inequality. They have to deal with prejudices about the female of the species being second-rate and incapable of doing 'man's work'. The Brontë sisters, for example, learnt that 'literature is a man's business' and the Cuban drummer Millo Castro Zaldarriaga knew 'that only boys were allowed to play drums. "Go home", they would shout at Millo. "This is not for girls"' (144). Some biographies deal with gender inequality by drawing a binary opposition between a child's desire and her family's attachment to social convention. For instance, Balkissa Chaibou, an activist from Nigeria, who loved learning and became a doctor, was forced to marry and expected to leave school. In other stories, women are helped by a male figure such as a father, brother, or uncle, yet in all of these cases, cultural conventions and norms around womanhood severely constrain or deny these women's agency.

The second trope that operates in the stories is that of achieving agency and selfdetermination over major life decisions and actions. Struggles to take control and go against the grain of dominant gender ideologies are at the heart of all of the biographies. ${ }^{25}$ The use of active language stresses the idea that these women exercise agency: they not only think, dream, and believe, but also have (or claim!) the capacity to act on their visions, thereby demanding their freedom and right to participate in public life. Rather than depicting the process of achieving consciousness of women's status, the stories foreground acts of decision. Many of the biographical sketches are constructed around pivotal moments of self-determination, in which the heroines challenge parents' or politicians' authority: they raise their voice, apply for law school, write a letter to the President, and go to court if they need to. Other lives, in which there is less or no struggle, simply show that the women portrayed pursued their passions. All of the 100 women are presented - and praised - as bright, brave, ambitious, strong-willed, and hardworking heroines. They have the virtue of 'perseverance', which, according to the authors, is their one 'common trait'. ${ }^{26}$ Ultimately, against all the odds, these women achieved whatever they strove for, thereby subverting social structures. The life stories collected in Goodnight Stories therefore follow a progressive narrative and promote progressive values relating to women's agency and emancipation. 
The book expresses a hopeful outlook on life by spreading the empowering message that positive change is possible for every woman, even if she faces difficult circumstances. One might wonder, though, what young readers take from these exceptional lives, which can be considered success stories. In the 1970s, critics questioned the effects of biographies intended for children that elevate their subjects as heroes to be admired or worshipped. Marilyn Jurich, for instance, wondered: 'What happens when the child finds he cannot become even close to that ideal?'27 Furthermore, she argued that overemphasising success and achievement can be misleading, because it suggests that 'fame and fortune come to those who work hard and that, conversely, those that have fame and fortune always deserve $i t^{\prime} .{ }^{28}$ One might add that young readers could be led to believe that a lack of success means that one did not work or try hard enough. Although the lives presented in Goodnight Stories do not omit imperfections and failures, their primary concern is to promote the optimistic message that those who persevere are capable of dealing with obstacles.

Women's agency is further highlighted by other aspects of the narrative composition, specifically those relating to the focalisation. Like fairy-tales, the stories all have third-person narrators. However, the women portrayed are the focalisers; the reader often gets direct or indirect access to their thoughts and feelings through interior monologues or imagined dialogues. The following lines from the life of Ruth Bader Ginsburg, the American Supreme Court judge who recently passed away, is a telling example: “"A lady lawyer? People would mock her. "Don't be ridiculous! Lawyers and judges are always men!" Ruth looked around her and saw that they were right. "But there's no reason why that shouldn't change", she thought to herself' (168). Bader Ginsburg's motto 'I dissent', which is displayed in the portrait provided alongside the written biography, further reinforces this mode of representation, which presents her as an agent.

Inspecting this feminist focus on female agency more closely, it is worth noting the absence of two central themes outlined here in traditional women's lives. First of all, unlike children's biographies of women from the nineteenth and twentieth centuries, Goodnight Stories is not centrally preoccupied with its subject's physical appearance. ${ }^{29}$ Aside from the physical features revealed in the graphic portraits, looks or clothes are only mentioned when they reveal how the woman concerned stayed true to herself and rebelled against societal norms. For instance, clothing style is a central theme in the life of surgeon Mary Edwards Walker, who, as a child, refused to wear the petticoats and corsets in which girls were expected to dress in nineteenth-century America. 
As an adult, she was arrested a couple of times for wearing men's clothes, but this did not stop her from dressing the way that she wanted. (126).

Secondly, the book scarcely treats reproduction and motherhood, even though many of the subjects had children (some wanted, others not); struggled with miscarriages and abortions; and variously desired to raise children or be childfree. Moreover, it seldom mentions how women had difficulties in combining motherhood and a career, and balancing their loyalties to work and the household..$^{30}$ Young readers might not realise, therefore, that being a 'rebel' often comes at a price and calls for sacrifices. Like motherhood, the theme of marriage is largely ignored. First and foremost, the presented women's lives shed light on their success in advancing or achieving gender equality in the workplace and society at large, rather than in marriage or love relationships with men. Critics who noticed this tendency in earlier biographies for children, raised the question of whether it is 'more acceptable to show women as resistors in society at large, but not as resistors in their own families, against their husbands?'31 Unlike these biographies, Goodnight Stories treats rebellion in the home, specifically when it comes to resisting fathers' authority.

The adjective 'first' is constantly repeated throughout the book so as to point out that these women were pioneers. Such is the case with Hatshepsut from Ancient Egypt, who was 'the ever first woman to become a pharaoh' (66); Ada Lovelace, the nineteenth-century mathematician 'who wrote the first computer program in history' (2); and Hillary Clinton, 'the first woman nominated by a major party for President of the United States (70). Although the priority of these women's achievements may have been confirmed, as a general principle the use of the word 'first' is questionable. This is because it ignores the possibility that these women were not the first to do what they did, but only the first to be noticed and mentioned by historians. In any case, the stories emphasise that these women made an impact on history and society; they shaped not only their own and others' lives, both during their lifetime and into the future. Even if only a little, they changed masculinist society by showing what women are capable of in terms of their intellect, courage, or strength. Accordingly, the stories present girl power as not just involving agency and ability, but influencing future generations too.

Favilli and Cavallo want to inspire young readers through their ideals. What is more, they want to put them in an active position and help them become agents of change. This is best exemplified by the graphic portraits, which are accompanied by a motto-a life lesson, belief, or value worthy of commitment-that is readily grasped and intelligible for children. Some mottos explicitly emphasise the importance of agency in order to foster a can-do mentality, such as Manal Al-Sharif's 'Go out and 
Drive' (106). This is even more clearly evidenced in the book's final two pages, which set the young reader an assignment. It involves envisioning herself (or himself): 'Write your own story'; 'Draw Your Portrait'. Having read 100 stories of impressive female characters, girls are enjoined to emulate them: 'adopt and enact the attributes of the empowered'. The authors have further elaborated on their didactic purpose in Goodnight Stories by publishing a companion to the book: a diary titled I am a Rebel Girl. It is full of exercises meant to train what Favilli and Cavallo call 'a rebel spirit' and 'get girls thinking, get girls dreaming, and most importantly, get girls doing' ${ }^{32}$

The lives presented in Goodnights Stories adhere to the same narrative frame and form, a configuration that establishes connections among the 100 featured women. Indeed, the collection lays bare how women have ceaselessly battled and successfully changed dominant gender norms in societies over history. This bears resemblances to how biographies for children have been used in progressive activism, such as the African American civil rights movement. ${ }^{33}$ Reading about the lives of black Americans serves to inform young children about their achievements and make them aware of the 'enduring struggle against oppression and discrimination' (idem). As critics have discussed in reference to black feminist biography, women's historical and contemporary struggles are often narrated in a way that invites active engagement:

In the context of Black feminist traditions, historical recounting of Black women's experiences serves the goals of both knowledge and empowerment. Recounting the past is meant to engender agency in the present. Agency is constituted simultaneously of an experience of freedom and a recognition that acting within that freedom has the potential to effect real change in one's world, whether in one's own community or beyond. ${ }^{34}$

Just as in this black feminist tradition, Goodnight Stories presents legacies of women's rebellion and emphasises the values of knowledge, empowerment, and agency. Moreover, it also elicits 'transhistorical identification' between women from different historical periods. ${ }^{35}$ Equipped with the knowledge 'to envision a history of resistance that extends both backward into the past and forward into the future', young 'rebel girls' are encouraged to continue this tradition. ${ }^{36}$ As such, they are addressed as both objects of concern and future inheritors of the feminist legacies. 


\section{The transnational scope and approach}

Goodnight Stories connects women not only across the ages, but among nations and continents too. Indeed, just as the collection's vast historical sweep suggests an enduring battle against sexisms, it also indicates that this is a worldwide struggle. As is clear by now, the women featuring in Goodnight Stories have been consciously selected to cover every continent. A glance at the subjects' countries of origin, which are given at the bottom of the page, reveals that the first volume alone represents over 40 countries, including Afghanistan, Argentina, China, Germany, Ghana, Greece, Jamaica, Japan, Mexico, Poland, Pakistan, Syria, and New Zealand. Moreover, the book itself can be considered a transnational collaborative project, for the two Italian authors, who live in the United States, asked 60 female illustrators from different countries to draw portraits accompanying their writing. It is likely that this international collaboration has enhanced the book's transnational reach. This was the authors' explicit purpose: indeed, the book is dedicated to 'the rebel girls of the world'.

Seen from this angle, Goodnight Stories differs from progressive biographies for children that are presented in national terms. For instance, in line with the educational tradition discussed above, the first children's biographies of George Washington and Benjamin Franklin to be published in the nineteenth century were intended to turn young American readers into 'model patriots' ${ }^{37}$ By stressing the so-called founding fathers' virtues and presenting them as exemplars of moral behaviour, these biographies engaged young readers and bound them to the national community. Biographies for children that served as educational tools for African American civil rights movement were also closely tied to American history. Indeed, they were clearly written with the aim of making young readers aware of individual African Americans' achievements and contributions to society. ${ }^{38}$

Goodnight Stories is necessarily transnational in scope, for it sets out to expose women's struggles against masculinist power in every corner of the globe. It must be said that there is an extent to which the collection of short biographies, all of which are written in the same narrative form, 'water[s] down the particular historical and sociopolitical context' of the women's life trajectories. ${ }^{39}$ After all, escaping dictatorship in Iran is different from fighting apartheid in South Africa or wanting to race in the Giro $\mathrm{d}^{\prime}$ Italia, the Italian cycling competition. What is more, poverty, to mention another circumstance faced by some of the featured women, is surely relative to a society's standard of living. Nevertheless, the book brings together women from different parts of the world and as such, it puts feminism in a global perspective. Seen in this light, 
the recent appearance of an exclusively Dutch edition of Goodnight Stories in 2021, seems somewhat inconsistent with the transnational scope of the book project. ${ }^{40}$ Nonetheless, it could be argued that the Dutch chapter likewise advances the idea that gender equality needs to be promoted across the globe, in both Western and non-Western countries. ${ }^{41}$

Goodnight Stories clearly suggests that feminism is not a European or Western invention. The book documents the forgotten or neglected stories of pioneering heroines who lived in ancient civilisations outside Europe and claimed their right to participate in public society. For example, they remind readers of the life of Egyptian Mathematician and Philosopher Hypatia (370-415), who developed theories of geometry and taught astronomy, attracting crowds of students. Notable too is Lakshmi Bai (18281858), a queen and warrior from India who assembled an army of 20,000 rebels to fight the British colonisers (96). Other, contemporary examples, such as the Nigerian activist Balkissa Chaibou and President of Mauritius Ameemah Gurib-Fakim, show that nonWestern women are involved in politics and occupy crucial leadership positions.

It will hardly come as a surprise that the biographies of contemporary politicians, among all of the book's subversive heroines-have triggered the most debate. According to some critics and readers, Hillary Clinton and Margaret Thatcher do not belong in a children's book of admirable role models for rebel girls. ${ }^{42}$ The most controversial example by far, however, is the female politician Aung San Suu Kyi. The Burmese leader protested against military dictatorship, lived under house arrest for many years, and was ultimately elected 'the leader of her country' (26). As Favilli and Cavallo write, 'She won the Nobel Peace Prize and inspired millions of people in her own country and across the world' (ibidem). She still seemed an icon of peace and democracy worthy of a biography when Goodnight Stories was first published in 2016. Once she had refused to denounce the persecution of Rohingya Muslims in Myanmar (which the UN described as 'ethnic cleansing'), however, her inclusion in the book drew fierce criticism. ${ }^{43}$ In response, the authors declared that they are 'monitoring the situation closely and don't exclude the idea of removing her from future prints'. ${ }^{44}$

\section{Translation and reception}

Interestingly, the book's translation, reception, and circulation bring to light differences as well as commonalities among nations and cultures. Although Goodnight Stories has generally been well received across the globe, it has also been met with bans 
and censorship in certain countries. As has already been mentioned, Turkey has partially banned the book because it was deemed detrimental to young girls. The publication of the book in Russian has also encountered difficulties. This edition features 99 women instead of 100 because the story of Coy Mathis, a transgender girl from the United States, has been removed. Instead, it leaves one page blank, intending for the readers to use it 'to add their own story'. The publisher declared that Mathis's story was excluded 'due to Russia's 2013 ban on the spreading "propaganda for non-traditional sexual relations" to minors' ${ }^{45}$ Clearly, the book's message-whether it is deemed progressive or not - has not been met with the same enthusiasm everywhere.

In countries with liberal political climates, in which the book is generally appreciated, differences reveal themselves at the level of translation. Indeed, comparing different language editions in Western European countries lays bare some striking cultural differences. It is not unusual for translators to make changes to the source text's pace, structure, and wording so as to best deliver its message to the target audience. Goodnight Stories' different editions show how some translators take more liberties in this process than others. Whereas the Italian, French, and German editions, for example, remain close to the book's original dedication 'To the rebel girls of the world', the Dutch edition changed it. Whereas, in the source, the dedication included the following English text, the Dutch translation deviated from it in several respects:

\author{
Volg je hart \\ Gebruik je hoofd \\ Doe je bovenste best \\ En als je valt: \\ Gewoon weer opstaan! ${ }^{46}$
}
[Dream bigger
Aim higher
Fight harder
And, when in doubt, remember
You are right.]

Dutch readers are encouraged to follow their hearts, use their brains, and try their best. The call to dream and fight is lost in the translation, let alone the injunctions to dream 'bigger', aim 'higher', and fight 'harder'. The Dutch translation thus tones down the drive to achieve. One can only speculate about this twist in translation. The translator 
could have been motivated by linguistic or aesthetic concerns, but the change may also have been prompted by cultural conventions in Dutch society. It is generally known that Dutch society prescribes ordinariness: Doe maar gewoon, dan doe je al gek genoeg! ['Just act normal, that's crazy enough!'], one Dutch saying goes. Although it is beyond the scope of this article to compare editions in other languages, within and beyond Europe, this topic is definitely worthy of further investigation. Shifts in translation may offer interesting insights into cultural differences with regard to the different ideas that nations invest in children, girls, and boys.

It will also be interesting to explore Goodnights Stories' transnational scope in more depth at the level of its outreach. The book series is part of the authors' larger project of building 'a global community of progressive parents'. Rebel Girls, the media company and publishing house behind Goodnight Stories, is very active on Facebook, Twitter, and other social media. It energetically reaches out to people from different countries in hope of bringing them together. Their successful Kickstarter campaign proves that the authors are effective fundraisers, having secured support for the publication of Goodnight Stories from sponsors around the world. Their campaign's website mentions that the community of backers, which helped bring the project to life, spans more than 70 countries. There are limits to this global community, however, in that the project's sponsors come largely from Western, English-speaking countries. Indeed, the ten countries in which the project has the most backers are the United States, United Kingdom, Canada, Australia, Italy, New Zealand, Germany, Singapore, Brazil, and Sweden. The marketing of Goodnight Stories is also interesting, for it shows that some parts of the world are targeted ahead of others. In an interview, one of the marketeers explained that the promotion campaigns were tied explicitly to Christmas shopping. ${ }^{47}$ This would suggest that they cater more to Christian dominated countries than Muslim countries, for instance.

Despite this, the book's sales figures and many translations demonstrate that it has reached readers in different parts of the world. Moreover, the fact that the Russian and Turkish governments have respectively censored and partially banned Goodnight Stories seems only to affirm the authors' view that the book can make an impact across borders - and indeed has done so already. Biographies for children still matter in the twenty-first century, that much is certain. It therefore seems worth mapping and examining the circulation of these books and comparing their reception among both adults and children in different contexts. 
More generally, analysing Goodnight Stories shows that biographies intended for children are a valuable source in the study of conceptions of gender and female identity across nations and cultures. Although the question of whether the project can be considered 'progressive' remains open, it is clear that the book's authors are responding to the gender inequalities that they perceive in contemporary societies and want to make a positive change. Like the black feminist tradition of biographies for children, their collection of women's lives is meant to empower young girls all over the world by making them aware of longstanding traditions of female rebellion and invite them to carry that tradition forward. Both within the narrated biographies and its address to child readers, it thereby constructs a transhistorical and transnational model of female agency and action, which is presented as a necessary tool in changing gender roles in societies around the world.

\section{Works Cited}

Agence France Presse in Istanbul, 'Turkey says Rebel Girls children's book should be treated like porn', in: The Guardian, 4 October 2019.

Beauvais, Clémentine, 'Bright Pasts, Brighter Futures: Biographies for Children in the Early Twenty-First Centuries', in: Nathalie op de Beeck (ed.), Literary Cultures and Twenty-First-Century Childhoods, Cham, Switzerland: Palgrave Macmillan, 2020, 5779.

Bland, Janice, Children's Literature and Learner Empowerment: Children and Teenagers in English Language Education, London, New Delhi, New York, Sydney: Bloomsbury, 2013.

Brown, Don, 'Profiles and Perspectives. Sifting through the Details. Writing Biographies for Children', in: Language Arts 84:6. Inquiries and Insights July (2007) 549551.

Dansberger Duque, Catalina Sofia, 'Q \& A: Elena Favilli and Francesca Cavallo on Good Night Stories for Rebel Girls and Why Children's Books Need Feminism', in: Ms Magazine, 26 June 2017. https://msmagazine.com/2017/06/26/good-night-stories-rebelgirls/date accessed: 26 October 2020.

Favilli, Elena and Francesco Cavallo, Goodnight Stories for Rebel Girls, London: Penguin Random House UK, 2017 [US Timbuktu Labs, 2016].

Gale, Eaton, Well-Dressed Role Models. The Portrayal of Women in Biographies for Children, Lanham, Maryland: Scarecrow Press, 2006. 
Haase, Donald (ed.), Fairy Tales and Feminism: New Approaches, Detroit: Wayne State University Press, 2004.

Jurich, Marilyn, 'What's Left out of Biography for Children?', in: Children's Literature 1 (1971) 143-151.

Lee, Hermione, Biography. A Very Short Introduction, Oxford: Oxford University Press, 2009.

Lowther, Tricia, ‘Why no stories for Rebel Children? Don't divide young readers by gender', in: The Guardian, 24 April 2018.

Merrick, Jane, ‘Parents demand Aung San Suu Kyi is cut from children's book of role models', in: The Guardian, 24 December 2017.

Samuel, Mounir, 'Rolmodellen', in: De Groene Amsterdammer, 16 November 2017. Online version. https://www.groene.nl/artikel/rolmodellen-kinderboek, date accessed: 30 June 2021.

Scott, Jon C., 'Biography for Children', in: Children's Literature 3 (1974) 245-248.

Stabell, Ivy Linton, 'Model Patriots: The First Children's Biographies of George Washington and Benjamin Franklin', in: Children's Literature 41 (2013) 99-114.

Tyler, Meagan, 'Was Margaret Thatcher a Rebel Girl?' https://www.feministcurrent.com/2017/11/16/margaret-thatcher-rebel-girl/, date accessed: 9 February 2021.

VanderHaagen, Sara, 'Practical Truths: Black Feminist Agency and Public Memory in Biographies for Children', in: Women's Studies in Communication (2012) 18-41.

Wilson, Rachel E., Amber R. Jarrard and Deborah J. Tippins, 'The Gendering of Albert Einstein and Marie Curie in Children's Biographies', in: Cultural studies of Science Education (2009) 4, 945-950.

Zervas, Theodore G., Formal and Informal Education during the rise of Greek Nationalism. Learning to be Greek, New York: Palgrave Macmillan, 2017.

\section{About the author}

Marleen Rensen is Senior Lecturer in Modern European Literature at the University of Amsterdam, the Netherlands. She is the author of many journal articles and book chapters, and co-editor of the volumes Transnational Perspectives on Artists' Lives (Palgrave, 2020) and Unhinging the National Framework: Perspectives on Transnational Life Writing (Sidestone,2020).

ORCID: https://orcid.org/0000-0002-6541-0022 


\section{Notes}

${ }^{1}$ ‘Turkey says Rebel Girls children's book should be treated like porn’, Agence France-Presse in Istanbul, The Guardian, Friday 4 October 2019.

${ }^{2}$ Francesca Cavallo quoted in the article from The Guardian 2019, ibidem.

${ }^{3}$ See for example VanderHaagen, Sara, 'Practical Truths: Black Feminist Agency and Public Memory in Biographies for Children', in: Women's Studies in Communication (2012) (20). On the use of short biographies for children in historical education in nineteenth-century Greece, see Zervas, Theodore G., Formal and Informal Education during the rise of Greek Nationalism. Learning to be Greek, New York: Palgrave Macmillan 2017, 96. Lastly, see an old but insightful article by Katharine Hazeltine Paton, 'Biography in Religious Education', in: Bible and Religion, vol. 8 no. 4 (1940).

4 Stabell, Ivy Linton, 'Model Patriots: The First Children's Biographies of George Washington and Benjamin Franklin', Children's Literature, vol. 41, (2013) (94).

${ }^{5}$ VanderHaagen, Sara (2012); Clémentine Beauvais, 'Bright Pasts, Brighter Futures: Biographies for Children in the Early Twenty-First Centuries', in: Nathalie op de Beeck ed. Literary Cultures and Twenty-FirstCentury Childhoods, Cham, Switzerland: Palgrave Macmillan, 2020 (57-79; 58-60).

${ }^{6}$ Beauvais, Clémentine, 2020 (59-60).

${ }^{7}$ Goodnight Stories for Rebel Girls received the Blackwell's Book of the Year Award in 2017 and the Australian Book Industry Award in 2018.

${ }^{8}$ Favilli, Elena and Francesco Cavallo, Goodnight Stories for Rebel Girls Penguin Random House UK 2017 (xi). Hereafter cited in the text.

${ }^{9}$ Dansberger Duque, Catalina Sofia, 'Q \& A: Elena Favilli and Francesca Cavallo on Good Night Stories for Rebel Girls and Why Children's Books Need Feminism', in: Ms Magazine, 26 June 2017. https://msmagazine.com/2017/06/26/good-night-stories-rebel-girls/. Date accessed: 16 February 2021.

${ }^{10}$ Favilli, Elena and Francesca Cavallo, Goodnight Stories for Rebel Girls 2 (2018); Elena Favilli and Pam Gruber, Goodnight Stories for Rebel Girls: Hundred Immigrant Women Who Changed The World (2020).

${ }^{11}$ https://www.kickstarter.com/projects/timbuktu/good-night-stories-for-rebel-girls-100-tales-todr/faqs. Date accessed: 16 February 2021.

${ }^{12}$ Lee, Hermione, Biography. A Very Short Introduction, Oxford: Oxford University Press, 2009 (19-39).

${ }^{13}$ Dansberger Duque, Catalina Sofia, 2017. They had two other principal criteria in making their selection: they wanted to include woman from both the past and the present and women whose biographies would be interesting to children.

${ }^{14}$ VanderHaagen, Sara, 2012 (18).

${ }^{15}$ Idem (1).

${ }^{16}$ Brown, Don, 'Profiles and Perspectives. Siftung through the Details. Writing Biographies for Children', in: Language Arts (2007) (550). See also Jurich, Marilyn, 'What's Left out of Biography for Children', Children's Literature, vol. 1 (1972) (143-151).

${ }_{17}$ The fact that Maya Angelou was raped in childhood or that Amelia Earhart's father was an alcoholic, for instance, are not mentioned either.

${ }^{18}$ Goodnight Stories, back cover.

${ }^{19}$ Haase, Donald ed., Fairy Tales and Feminism: New Approaches, Detroit: Wayne State University Press, 2004. This volume discusses the complex and ambiguous relationship between women and fairy tales and presents new approaches in recent feminist fairy tale studies.

${ }^{20}$ See for example https://www.bbc.com/news/education-39115031. Date accessed: 21 October 2020. 
${ }^{21}$ Lowther, Tricia, 'Why no stories for Rebel Children? Don't divide young readers by gender', in: The Guardian 24 April 2018.

${ }^{22}$ Cited in the article of Tricia Lowther, ibidem.

${ }^{23}$ From the Kickstarter Campaign: https://www.kickstarter.com/projects/timbuktu/good-night-storiesfor-rebel-girls-100-tales-to-dr. Date accessed: 16 February 2021.

${ }^{24}$ VanderHaagen, Sara (2012), 19. This article mentions slightly different tropes. Given that VanderHaagen discusses fully-fledged biographies, these tropes are more focused on the process of achieving consciousness.

${ }^{25}$ Bland, Janice, Children's Literature and Learner empowerment: Children and Teenagers in English Language Education, London [etc.]: Bloomsbury, 2013.

${ }^{26}$ Interview with the authors: https://www.maisonette.com/le scoop/5-questions-for-the-rebel-girls. Date accessed: 16 February 2021.

${ }^{27}$ Jurich, Marilyn, $1971(143,149)$.

${ }^{28}$ Idem (149).

${ }^{29}$ Eaton, Gale, Well-Dressed Role Models. The Portrayal of Women in Biographies for Children, Lanham, Maryland: Scarecrow Press, 2006. Gale notes that the genre has gradually become more gender-sensitive.

${ }^{30}$ One exception is the sketch of the life of Margaret Thatcher, which mentions that, at first, she 'was not even considered [for elections], because the men in her party thought that a young mother would be unsuitable for life in parliament' (110). The sketch does not describe how she combined her loyalties to work and the home in any further detail. Another tale to mention motherhood is that concerning the computer scientist Margaret Hamilton, who 'brought her daughter Lauren to work in the weekends and evenings' (108).

${ }^{31}$ Wilson, Rachel E. et al., 'The gendering of Albert Einstein and Marie Curie in children's biographies', in: Cultural studies of Science Education (2009) (947).

${ }^{32} \mathrm{https}$ //www.maisonette.com/le_scoop/5-questions-for-the-rebel-girls

${ }^{33}$ VanderHaagen, Sara, 2012 (21)

${ }^{34}$ Idem (23).

${ }^{35} \operatorname{Idem}(19,35$ note 3$)$.

${ }^{36} \operatorname{Idem}(34)$

${ }^{37}$ Stabell, Ivy Linton, 2013.

${ }^{38}$ VanderHaagen, Sara, 2012 (21).

${ }^{39}$ Scott, Jon C., 'Biography for Children', in: Children's Literature, vol. 3. (1974).

${ }^{40}$ Bedtijdverhalen voor rebelse meisjes. 100 Bijzondere Nederlandse vrouwen. Amsterdam: Rose Stories 2021

${ }^{41}$ Samuel, Mounir, 'Rolmodellen', in: De Groene Amsterdammer, 16 November 217. Online version. https://www.groene.nl/artikel/rolmodellen-kinderboek. Date accessed: 30 June 2021.

${ }^{42}$ See for example: Tyler, Meaga,. 'Was Margaret Thatcher a Rebel Girl?' https://www.feministcurrent.com/2017/11/16/margaret-thatcher-rebel-girl/. Date accessed: 16 February 2021.

${ }^{43}$ Merrick, Jane, 'Parents demand Aung San Suu Kyi is cut from children's book of role models', in: The Guardian, 24 December 2017.

${ }^{44}$ Ibidem.

45 See for example these articles: https://www.huffpost.com/entry/russia-lgbtq-books-removal n 5be2ec62e4b0e84388924c5d; and https://www.mhpbooks.com/under-recent-propagandalaw-russian-publishers-are-erasing-queer-stories-from-forthcoming-titles/

${ }^{46}$ Bedtijdverhalen voor rebelse meisjes, translated by Monique ter Berg. Amsterdam: Rose Stories, 2017.

${ }^{47}$ See for example https://www.thebookseller.com/insight/turning-good-night-great-one-729111.

Date of Access: 10 February 2021. 